\title{
Work Related Stressors and Teachers' Performance: Evidence from College Teachers Working in Punjab
}

\author{
Dr. Rizwan Qaiser Danish \\ Assistant Professor, Hailey College of Commerce, \\ University of the Punjab, Lahore, Pakistan \\ Ms. Shumaila Qaseem \\ Ms. Tayyaba Mehmood \\ Qazi Muhammad Ali \\ Superior University, Lahore, Pakistan \\ Hafiz Fawad Ali \\ M.B.A/MPhil Institute of Business Administration \\ University of the Punjab, Lahore, Pakistan \\ Ms. Rabia Shahid \\ Hailey College of Commerce, PU, Lahore, Pakistan
}

Doi:10.19044/esj.2019.v15n4p158 ～URL:http://dx.doi.org/10.19044/esj.2019.v15n4p158

\begin{abstract}
This study is conducted to determine the impact that job stress (job conflict, work overload, inadequate reward policy and job burnout) has on teacher's job outcomes (employee loyalty and employee performance). In order to explain the relationship among the variables, hypothesis testing was used since the study is causal. This paper focuses on teachers of five best intermediate level colleges of Lahore and a sample size of 100 respondents. The independent variable of the study is work related stressors (job conflict, work overload, inadequate reward policy, and job burnout), while dependent variable is teachers' performance (employee loyalty and employee performance). SPSS version 20 was used for the initial analysis of collected data (descriptive statistics, reliability analysis, and correlation). Furthermore, SEM using AMOS is applied for checking the fitness of the model as well as the relationship among dependent and independent variables. The analyzed results show impact of all independent variables on dependent variables. However, job conflict, job burnout, and inadequate reward policies have significant impact on teacher's performance. The largest influence comes from job conflict and job burnout on employee loyalty and inadequate reward policy on employee performance.
\end{abstract}


Keywords: Job conflict, work overload, inadequate reward policy, job burnout, employee loyalty, employee performance

\section{Introduction}

Scholars and academic researchers agreed that teaching is most critical yet a gentle social profession which creates all other professions in the whole world. Teaching is a distinct and an important profession in this world because all other professions grow and are sustained due to this profession (Hanif, 2004). Teachers are expected to produce logical thinkers who will contribute important and effective inputs for a society. Teachers are also base stones for the advancement and development of the society. Today, education is becoming a business where teachers are under-paid employees like other industries and students are the customers. This badly affects the teacher's mental health and creates job stress. Stress is an emotional response towards any condition that affects any individual's health. According to Selye (1978), stress can be defined as an inner force or outer actions that disturb the individual stability.

Stress is said to be a response of an individual towards harmful effects such as irritation and helplessness that becomes a threat to his/her self-respect. Particularly, job stress is related with mental stress and pressure that is associated with worker's capabilities to react and handle any situation at their workplace thoughtfully (Kyriacou \& Sutcliffe, 1978). In other words, it is related with all those dangerous emotional responses of employees where their skills and abilities are not well matched with job demands (Chen \& Silverthorne, 2008). Workload, organizational constraints, problems in the classroom, and interpersonal conflicts are the major factors that contribute to teachers stress (Moore, 2002; Mrozek, 2004). Role conflict, role ambiguity, workload, and workplace conflict are factors of stress known as stressors (Addae, Parbooteah \& Velinor, 2008).

Teacher's stress level is also increased when they do not get proper social status in the economy. A teacher is regarded as a person with highquality skill but no standard power. Shah, Ali and Khan (2012) is of the view that Pakistani teachers are normally disappointed with their societal status. However, these situations have become a foundation of societal distress, where teachers believe that there is no proper system of improving social status associated to their profession (Humphrey, 2002).

Job stress negatively affects employee's job performance which creates lower job satisfaction and decreased quality of output (Tetrick \& Larocco, 1987). Job performance is significantly important for organizations, individuals, and colleges alike. Individuals feel self-efficacy, satisfaction, and motivated when tasks are properly accomplished by showing high performance (Sonnentag et al., 2010). There are many definition of job 
performance which shows the complication and complicated nature of the concept. Selamat, et al. (2013) defined teacher's job performance to be how teachers behave while teaching and it is directly related with teacher's effectiveness.

Originally, teaching profession is among the less stressful profession. According to Fisher (1994), teaching profession has less workload, work independence, and elastic working hours. However, with the appearance of political and socio-economic trends, working of educational institutions have changed a lot and now teaching is considered as one of the tough profession (Winefield, Gillespie \& Dua, 2003). Job burnout is another factor related to job stress. Teacher's job performance and loyalty is affected by job burnout. Maslach et al. (2001) indicates that lower productivity and effectiveness are the problems related to burnout, and it has negative impact on their colleagues by disturbing job tasks and results to more personal conflicts. Ashtari et al. (2009) is of the view that job burnout and failure during job performance are significantly correlated.

\section{Literature Review}

\subsection{Work Related Stressors}

Educational institutions face unstable environment and insecurity. Responsiveness and adaptability of the teachers have become key elements of the success of the educational institutions. In fact, teachers should be given a competitive environment that requires methods of organizing complex dimensions of performance to reduce work related stressors, in order to push teacher's to develop high level of performance and creativity (Bolwijn \& Kumpe, 1990).

\subsubsection{Job Role Conflict}

Job role conflict is a situation that arises when role requirement of a person is incompatible. Another reason for job role conflict is ambiguous job tasks and not having desire to do those things which are demanded (Seller \& Damas, 2002). According to Latham (2013), there may be three types of role conflict: firstly, it can be a conflict between a person and its role; the second type is related with the conflicting expectations of the techniques of performing the role - this type of conflict occurs when the person's values and attitudes do not match the role obligations; and the third type of role conflict arises due to diversified requirements to perform two or more roles at the same time.

Workplace problems create many types of conflicts in the workplace, whether conflicts are small, medium or large (Fahmi, 2017). Conflicts happen to be on personal level, intergroup or may be on organizational level (Luthan, 2006). One important example of conflict is between family and work which 
is experienced by people working in different organizations (Luthan, 2006). Conflicts also arise when multiple roles are demanded to be performed by humans. Stress would be dominant in job when people have no proper or clear description of their duties (Zhao et al., 2010).

\subsubsection{Research Questions}

This paper is focused on the following research questions.

11. What is the impact of job stress on employee loyalty?

12. What is the impact of job stress on employee performance?

13. What is the impact of job stress on teacher's job outcomes?

\subsubsection{Work Overload}

Work overload is a term used as awareness related to the availability of improper time and energy to meet the expectations of supervisors as well as to meet work demands (Leiter \& Schaufeli, 1996). When a person has too much work to do, it is known as work overload. Work overload can also be explained as performing too much work that is difficult at the same time (Ali \& Farooqi, 2014).Work overload is negatively related with employees health both physically and mentally which in turn affects the overall outcome of any organization (Morter, 2010; Bozkurt, Aytac, Bondy, \& Emirgil, 2012; Vanishree, 2014; Taştan, 2014). Numbers of occupational stress factors like work overload, work relations with others, and lack of job security are negatively related to job satisfaction (Paktinat \& Rafeei, 2012).

\section{- Inadequate Reward Policy}

For the achievement of companies objectives, an adequate reward policy is required that emphasizes on employee gain based on the time and effort they vested towards the growth of the company (Sutherland, 2004). A well-managed reward policy can be used as an instrument for motivation and retention of employees in any organization (Carrel et al., 1992; Terera \& Ngirande, 2014).

According to a study conducted in 2006, almost $45 \%$ companies lose brilliant employees due to inadequate rewards. According to $71 \%$ of employees, the major reason of quitting job is unjustified pay (White, 2006). When proper reward systems are understood and implanted in the organization, creative employees stays (Shechtman, 2008). An appreciated worker is more likely to stay in organization than an unappreciated worker. According to Sutherland (2004), reward system should be an important area of improvement for employers. 


\subsubsection{Job Burnout}

Teacher's level of commitment with organization is mainly dependent on one of the important factor called teachers job burnout. According to Gemlik et al. (2010), there is an association between job burnout and level of commitment with organization. In different working sectors, job related burnout is at a major level which results in decrease in job performance and level of job satisfaction (Maslach \& Leiter, 2008). Burnout is an outcome of inequality between job load and job resources (Bakker \& Demerouti, 2007).

\section{2 Teacher's Performance}

\subsubsection{Employee Loyalty}

Many researchers have defined the term teacher's loyalty in different ways. Teacher loyalty occurs when a teacher feels attachment towards the organization (Meyer \& Allen, 1991). There are two main dimensions of loyalty discussed by Seema, which are internal and external. Internal dimensions include emotional factors like feeling of association and responsibility, while external dimension is related to the techniques of loyalty established (Mehta, Singh, Bhakar, \& Sinha, 2010). Loyal employees are supposed to be completely related with elevated service excellence (Heskett et al., 1994). However, Silvestro and Cross (2000) have recognized inverse association between employee loyalty and their performance in the industry they researched.

\subsubsection{Employee Performance}

Previous research shows that performance of teachers is directly related to the reward system of organizations (Ubom \& Joshua, 2004). Although teachers are required to provide elevated job presentation as they have critical responsibility in the educational sector. However, teachers are accused of being lazy, lethargic, and having lack of dedication towards work. On the other hand, teachers view point is that inequitable incentive systems of organizations are basic factors behind their dissatisfaction or lack of performance (Ubom \& Joshua, 2004). Diversified results have been found with regards to the association between job performance and job stress. Westman and Eden (1996) explore the impact on job performance due to unnecessary work demands. 


\section{Research Model}

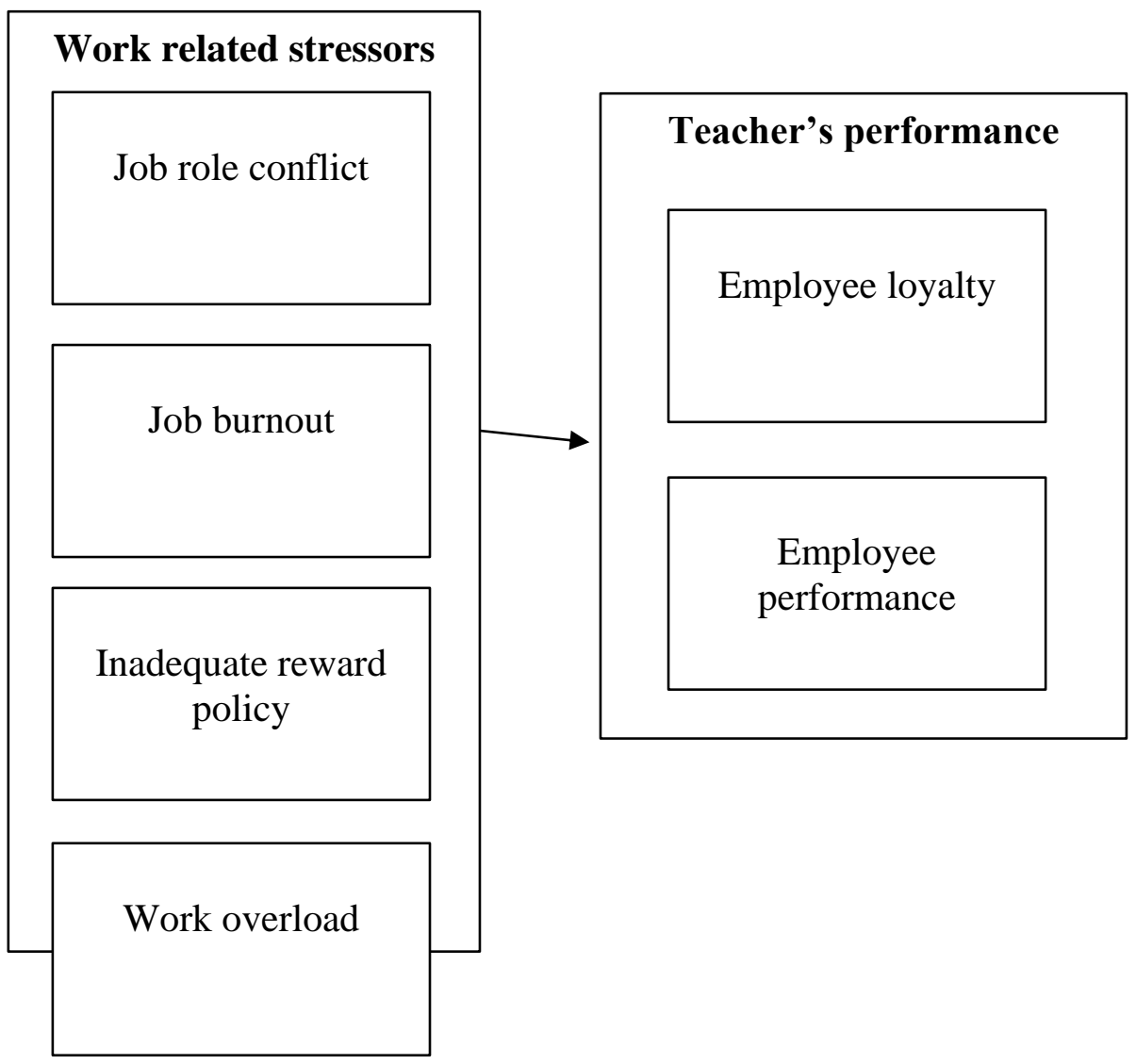

\section{Hypothesis}

H1.There is significant impact of work related stressors on employee performance loyalty

H1a. There is significant impact of job role conflict on employee

H1b. There is significant impact of job burnout on employee loyalty

H1c.There is significant impact of inadequate reward policy on employee loyalty

H1d.There is significant impact of work overload on employee loyalty

H1e.There is significant impact of job role conflict on employee performance

H1f.There is significance impact of job burnout on employee performance

H1i.There is significant impact of inadequate reward policy on employee performance 
H1j.There is significant impact of work overload on employee performance

\section{Research Methodology}

The key objective of this research is to uncover the pressure of work related stressors (job role conflict, work overload, inadequate reward policy and job burnout) on teacher's performance (employee loyalty and employee performance). Descriptive study is applied in this research. Descriptive data allows the researcher to get information according to the research. Targeted population of this research is the teaching staff of the best five intermediate level colleges of Lahore, Pakistan. This research was supported to represent which factors have the important impact on the teacher's job outcomes. A sample size of 100 was used in this study with a total of $65 \%$ female respondents and 35\% male respondents. Survey method is used in this study for gathering data, while questionnaire is used as an instrument to find out the results of this research. SPSS statistics is used for the analysis of data which consists of demographic analysis, reliability analysis as well as correlations to check the impact of independent variables on dependent variables. Furthermore, SEM (structural equation modeling) using AMOS (Analysis of moment structure) is applied to check the fitness of the model and the relationship of the studied variables.

\section{Results}

There are different types of data analysis techniques which are available. This study uses the SPSS (Statistical Package for Social Sciences) to analyze the data.

\begin{tabular}{|c|c|c|c|c|c|c|}
\hline & $\begin{array}{c}\text { Job } \\
\text { conflict }\end{array}$ & $\begin{array}{c}\text { Work } \\
\text { overload }\end{array}$ & $\begin{array}{c}\text { Correlation } \\
\text { Inadequate } \\
\text { reward } \\
\text { policy }\end{array}$ & $\begin{array}{c}\text { Job } \\
\text { burnout }\end{array}$ & $\begin{array}{c}\text { Employee } \\
\text { loyalty }\end{array}$ & $\begin{array}{c}\text { Employee } \\
\text { performance }\end{array}$ \\
\hline Job conflict & 1 & $.489^{* *}$ & $.401^{* *}$ & $.365^{* *}$ & $.497^{* *}$ & .167 \\
\hline $\begin{array}{c}\text { Work } \\
\text { overload }\end{array}$ & & 1 & $.269^{* *}$ & $.518^{* *}$ & $.221^{*}$ & .188 \\
\hline $\begin{array}{c}\text { Inadequate } \\
\text { reward policy }\end{array}$ & & 1 & $.232^{*}$ & $.272^{* *}$ & $.473^{* *}$ \\
\hline Job burnout & & & & 1 & $.402^{* *}$ & .118 \\
\hline $\begin{array}{c}\text { Employee } \\
\text { loyalty }\end{array}$ & & & & & 1 & .097 \\
\hline $\begin{array}{c}\text { Employee } \\
\text { performance }\end{array}$ & & & & & & 1 \\
\hline
\end{tabular}

Correlation procedure is used to show that if there is a change in the value of one variable, there is also a definitive change in the value of the other variable. This change can be positive, negative, weak or strong. Pearson 
correlation is used to check the significant association of correlation among variables. The relation between job conflict and employee loyalty is positive and significant $(\mathrm{p}=.497 * *)$ while the relation between job conflict and employee performance is positive but not significant $(\mathrm{p}=.167)$. Work overload have significant positive relation with employee loyalty $(\mathrm{p}=.221 *)$. However, it is positive with employee performance relation but not significant ( $\mathrm{p}=.188)$. Inadequate reward policy have positive significant relation with both employee loyalty $(\mathrm{p}=.272 *)$ and employee performance $(.473 * *)$. Job burnout have positive and significant relation with employee loyalty $\left(\mathrm{p}=.402^{* *}\right)$ and it is positive but has an insignificant relation with employee performance $(\mathrm{p}=.188)$. From the above given table, it can be concluded that all mentioned independent variables have more significant positive relation with employee loyalty compared to employee performance.

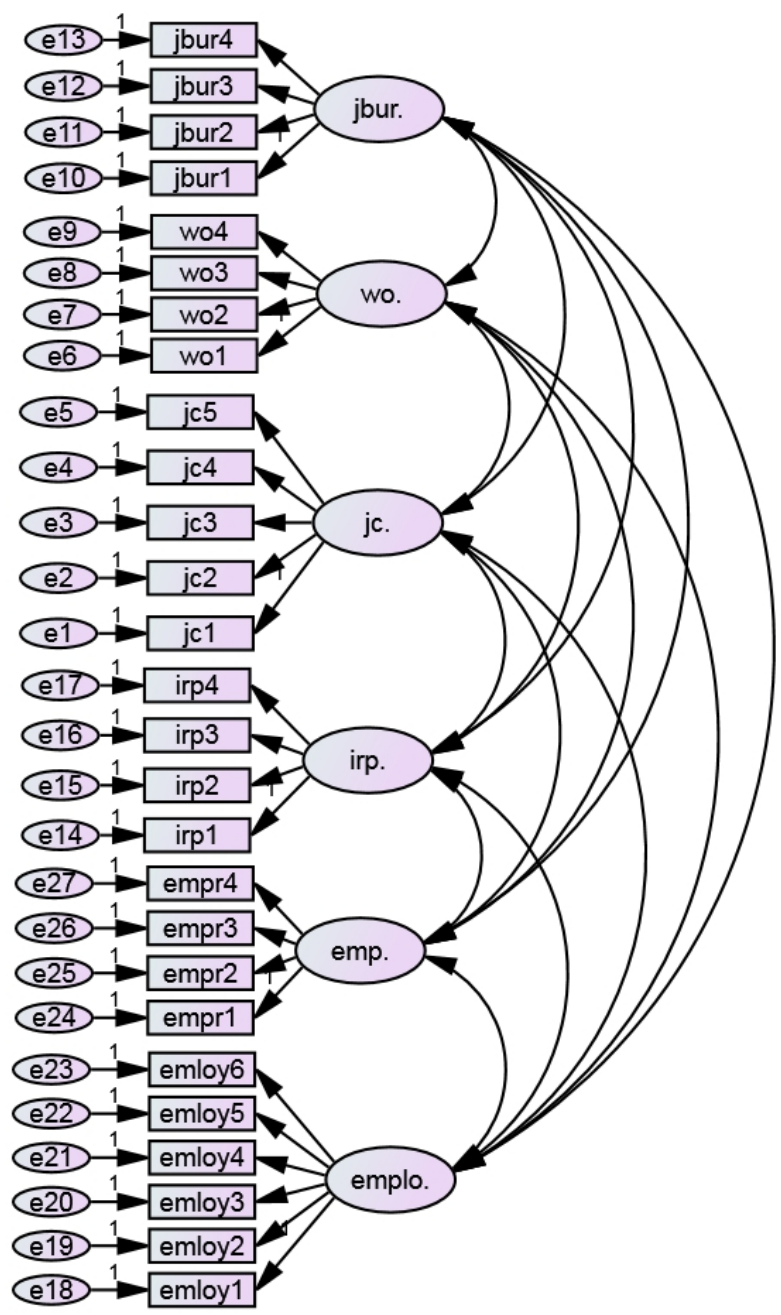

Figure 1: Measurement Model 
Table 2. Standardized Regression Weights

\begin{tabular}{|c|c|c|}
\hline & Estimates & P -value \\
\hline empr $1 \leftarrow---$ empr & .530 & $* * *$ \\
\hline empr $2 \leftarrow---$ empr & .538 & $* * *$ \\
\hline empr3 $\leftarrow---$ empr & .614 & $* * *$ \\
\hline empr4 Ł--- empr & .538 & $* * *$ \\
\hline emloy3 $\leftarrow--$ employ & .490 & $* * *$ \\
\hline emloy2 <-- employ & .501 & $* * *$ \\
\hline emloy1 $\leftarrow--$ employ & .550 & $* * *$ \\
\hline emloy4 Ł-- employ & .325 & $* * *$ \\
\hline emloy5 <-- employ & .753 & $* * *$ \\
\hline irp1 $\leftarrow---\operatorname{irp}$ & .502 & $* * *$ \\
\hline $\operatorname{irp} 2 \leftarrow---\operatorname{irp}$ & .771 & $* * *$ \\
\hline irp3 $\leftarrow---$ irp & .793 & $* * *$ \\
\hline irp4 Ł--- irp & .695 & $* * *$ \\
\hline jbur1 $\leftarrow-$ jbur & .564 & $* * *$ \\
\hline jbur $2 \leftarrow--$ jbur & .882 & $* * *$ \\
\hline jbur3 $\leftarrow--$ jbur & .884 & $* * *$ \\
\hline jbur4 $\leftarrow-$ jbur & .794 & $* * *$ \\
\hline jc1 $\leftarrow-$ jc & .397 & $* * *$ \\
\hline jc4 $\leftarrow--$ jc & .689 & $* * *$ \\
\hline jc5 $\leftarrow--$ jc & .595 & $* * *$ \\
\hline jc3 $<--$ jc & .822 & $* * *$ \\
\hline wo1 $\leftarrow$ - wo & .478 & $* * *$ \\
\hline wo $2 \leftarrow$ - wo & .487 & $* * *$ \\
\hline wo3 $\leftarrow$ - wo & .360 & $* * *$ \\
\hline wo4 $\leftarrow$ - wo & .759 & $* * *$ \\
\hline
\end{tabular}

Table 2 shows that all factor loadings are above from 0.36 .

Table 3. Model Fit Summary

\begin{tabular}{|c|c|c|c|c|c|c|c|}
\hline MODEL & CMIN/DF & RMR & GFI & AGFI & CFI & RMSEA & PCLOSE \\
\hline Job Conflict & .790 & .036 & .992 & .959 & 1.00 & .000 & .536 \\
\hline Work Overload & 1.075 & .017 & .989 & .944 & .996 & .028 & .427 \\
\hline Inadequate Reward & 1.304 & .026 & .987 & .933 & .991 & .055 & .355 \\
\hline Job Burnout & 1.754 & .021 & .991 & .913 & .996 & .087 & .238 \\
\hline Employee Loyalty & .640 & .020 & .994 & .968 & 1.00 & .000 & .604 \\
\hline Employee Performance & .723 & .019 & .985 & .956 & 1.00 & .000 & .722 \\
\hline
\end{tabular}




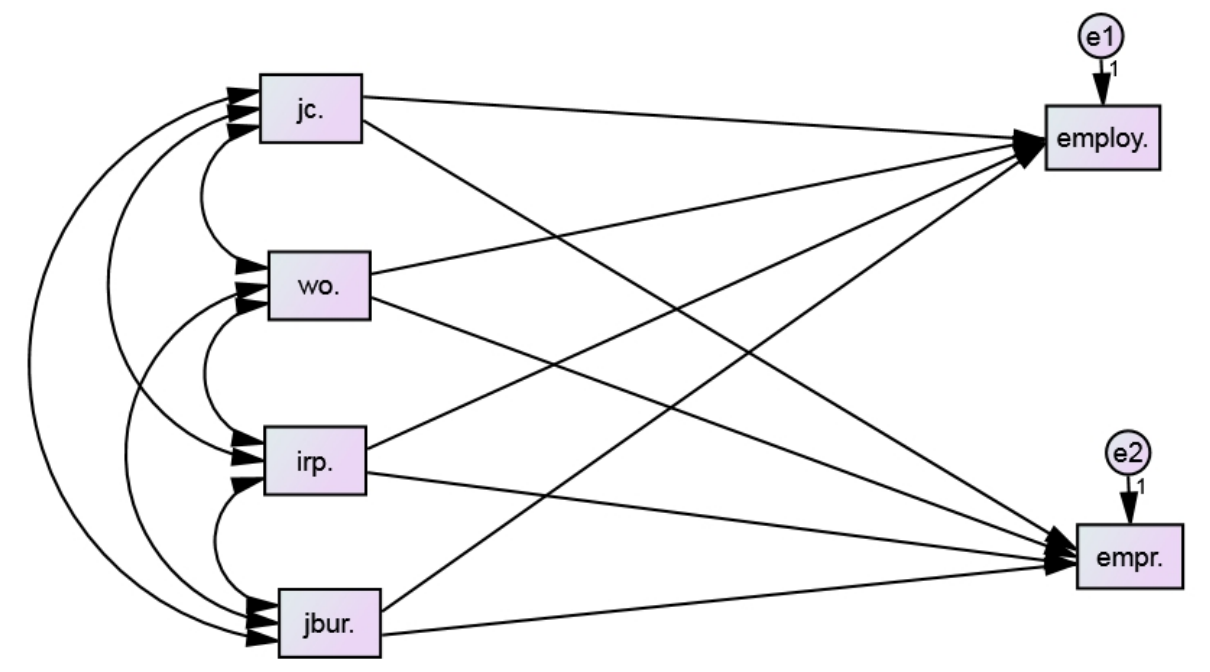

Table 4. Regression Weights

\begin{tabular}{|rrr|rr|}
\hline & & & Estimate & P \\
\hline employ. & $<---$ & jc. & .010 & .668 \\
employ. & $<---$ & wo. & 1.250 & $* * *$ \\
employ. & $<---$ & irp. & .047 & .009 \\
employ. & $<---$ & jbur. & .013 & .399 \\
empr. & $<---$ & jc. & -.023 & .788 \\
empr. & $<---$ & wo. & .588 & $* * *$ \\
empr. & $<---$ & irp. & .179 & .008 \\
empr. & $<---$ & jbur. & -.010 & .862 \\
\hline
\end{tabular}

Model fit was analyzed by various tested fit statistics (i.e. Comparative Fit Index (CFI), root mean square error of approximation (RMSEA), and goodness of fit index (GFI). The fitness of the proposed model was acceptable $\mathrm{CFI}=.995$, GFI $=.992$, $\mathrm{RMSEA}=.026$ which shows that the model was exceptionally fit.

Examination of the standardized parameter estimates was not fully supported H1. That is, job conflict has a significant impact on employee loyalty. $\mathrm{H} 2$ was also not supported that job conflict has a significant impact on employee performance. In supporting $\mathrm{H} 3$, work overload has a significant impact on employee loyalty. Supporting H4, work overload has a significant impact on employee performance. In supporting H5, inadequate reward has a significant impact on employee loyalty. Supporting H6, inadequate reward has 
a significant impact on employee performance. $\mathrm{H} 7$ and $\mathrm{H} 8$ are not supported in this study.

\section{Conclusion and Discussion}

The data was collected from the best five public and private sector intermediate level college teachers from Lahore. It is an identified reality that both public and private sectors are important sectors of Pakistan. Findings from the collected data shows that management of both sectors should focus more on resolving the issues of job conflict and job burnout to have loyal employees due to the fact that both job burnout and job conflict shows significant relation with employee loyalty. Also, for the enhancement of employee performance, management needs to revive the reward policies because inadequate reward policies have significant relation with employee performance. According to the research, these three factors are the major reason of stress among teachers which affects their job outcomes.

\section{Recommendations}

Management of both the public and private sector should be more focused towards

- Reducing the job burnout among employees,

- Clear instructions related to job duties and responsibilities should be given to employees to reduce job conflict, and

- Improve the system of rewards in the college to get better performances from teachers.

\section{Limitations}

Only the five best intermediate level colleges of Lahore are selected and data was taken from the teachers of these colleges. This research can be conducted on a broader level in other cities and in more colleges as well. Limited numbers of independent variables are researched with respect to job stress. According to the findings of this study, work overload can be explored further.

\section{References:}

1. Ahmad, M. B., Ali, H. F., Malik, M. S., Humayun, A. A., \& Ahmad, S. (2019). Factors Affecting Impulsive Buying Behavior with mediating role of Positive Mood: An Empirical Study. European Online Journal of Natural and Social Sciences, 8(1), pp-17.

2. Addae, H. M., Praveen Parboteeah, K., \& Velinor, N. (2008). Role stressors and organizational commitment: public sector employment in St Lucia. International Journal of Manpower, 29(6), 567-582. 
3. Ashtari, Z., Farhady, Y., \& Khodaee, M. R. (2009). Relationship between job burnout and work performance in a sample of Iranian mental health staff. African journal of psychiatry, 12(1), 71-74.

4. Ali, S., \& Farooqi, Y. A. (2014). Effect of work overload on job satisfaction, effect of job satisfaction on employee performance and employee engagement (a case of public sector University of Gujranwala Division). International Journal of Multidisciplinary Sciences and Engineering, 5(8), 23-30.

5. Ahmad, Z. \& Taylor, D. (2009). Commitment to independence by internal auditors: the effects of role ambiguity and role conflict, Managerial Auditing Journal, 24 (9)899 - 925.

6. Bhagat, R.S., McQuaid, S.J., Lindholm, H. \& Segovis, J. (1985). Total life stress: a multimethod validation of the construct and its effects on organizationally valued outcomes and withdrawal behaviors. Journal of Applied Psychology, 70,202-41.

7. Bennet, P., Lowe, R., Matthews, V., Dourali, M. \& Tattersall, A. (2001). Stress in nurses: coping, managerial support and work demand Stress and Health, 17, 55-63.

8. Butt, G. (2005). Secondary teacher workload and job satisfaction. Do successful strategies for change exist? Educational Management Administration Leadership 33(4), 401-422.

9. Bakker, A.B., \& Demerouti, E. (2008). Towards a model of work engagement. Career development international, 13(3), 209-223.

10. Bozkurt, V., Aytaç, S., Bondy, J., \& Emirgil, B.F. (2011). Job satisfaction, role overload and gender in Turkey. Sociology Conferences, 44, 4968.

11. Bakker \& E. Demerouti (2007). The Job Demands Resources model: state of the art. Journal of Managerial Psychology, 22(3): 309-328.

12. Chen, J.-C., \& Silverthorne, C. (2008). The impact of locus of control on job stress, job performance and job satisfaction in Taiwan. Leadership \& Organization Development Journal, 29(7), 572582.

13. Cappelli, P., Bassi, L., Katz, H., Knoke, D., Osterman, P., \& Useem, M. (1997). Change at Work. New York: Oxford University Press, 198 Madison Avenue, New York, NY 10016.

14. Carrell, M.R., Kuzmits, F.E., \& Norbert, F.E., (1992). Personnel Management/Human Resource Management (4th ed), (C) Macmillan Publishing Company, Inc., USA

15. De Jonge, J., Dollard, M.F., Dormann, C., Le Blanc, P.M., \& Houtman, I.L. (2001). The demand-control model: Specific demands, specific control, and well-defined groups. International Journal of Stress Management, 7(4), 269-287. 
16. Danish, R. Q., Shahid, R., \& Ali, H. F. (2019). Factors Affecting life Satisfaction of Employees under Financial Threat. SEISENSE Journal of Management, 2(1), 85-98.

17. Danish, R. Q., Ali, Q., Mahmood, T., Qaseem, S., Ali, H. F., \& Ahmad, M. B., (2019). Journal of Harmonized Research in Management.

18. Fahmi Irham(2011). Financial Statement Analysis. Lampulo: Alfabeta

19. Feldman, D.C. (1976). A contingency theory of socialization. Administrative Science Quarterly, 21. 433-52.

20. Fisher, S. (1994). Stress in academic life: The mental assembly line. Open University Press.

21. Gemlik, N., Sisman, F. A., \& Sigri, U. (2010). The relationship between burnout and organizational commitment among health sector staff in Turkey. Journal of Global Strategic Management, 8, 137-149.

22. Hanif, R. (2004). Teacher stress, job performance and self-efficiency of women school teachers. M.Phil Thesis, in National Institute of Psychology, Center of Excellence, Quaid-i-Azam University, Islamabad.

23. Humphrey, J. H. (2002). An anthology of stress: selected works of James H. Humphrey: Nova Science Publishers.

24. Heskett, J.L., Jones, T.O., Loveman, G.W., Sasser Jr., W.E., \& Schlesinger, L.A. (1994). Putting the service-profit chain to work. Harvard Business Review 72 (2), 164-174.

25. House, J. S. (2007). Occupational Stress and Coronary Heart Disease: A Review and Theoretical Investigation. Journal of Health Social Behaviour, 4, 17-27.

26. Higgins, C.A., Duxbury, L.E. \& Irving, R.K. (1992). Work-family conflict in the dual career family. Organizational Behavior and Human Decision Processes; 51, pp.51-57

27. Kyriacou, C., \& Sutcliffe, J. (1978). Teacher Stress, Prevalence, Sources and Symptoms. Journal of Educational Psychology, 48, 323365.

28. Kahn, R.L., Wolfe, D.M., Quinn, R.P., Snoek, J.D. \& Rosenthal, R.A. (1964). Organizational Stress: Studies in Role Conflict and Ambiguity, John Wiley \& Sons, New York.

29. Luthans F. (2013). Organizational behavior: an evidence based approach, McGraw Hill, New Delhi.

30. Luthans, F. (2006). Organizational Behavior 10th Editions, Edisi Bahasa Indonesia, Perilaku Organisasi, Andi, Yogyakarta

31. Lankau, M., Carlson, D.S. \& Nielson, T.R. (2006). The mediating influence of role stressors in the relationship between mentoring and job attitudes. Journal of Vocational Behavior, 68, pp. 308-322. 
32. Leiter, M.P., \& Schaufeli, W.B. (1996). Consistency of the burnout construct across occupations. Anxiety, Stress, and Coping, 9(3), 229243.

33. Mrozek, K. (2004). Teacher stress (Unpublished Manuscript).

34. Moore, W. (2002). Teachers and stress: pressures of life at the chalkface. Channel4 news.

35. Maslach, C., Jackson, S. E. \& Leiter, M. P. (2001). Job Burnout. Annual Review of Psychology, 52(1), pp. 397-422.

36. Mapfumo, J. S., Chitsiko, N., \& Chireshe, R. (2012). Teaching practice generated stressors and coping mechanisms among student teachers in Zimbabwe. South African Journal of Education, 32,155-166.

37. Maslach, C., \& Leiter, M. P. (2008). Early predictors of job burnout and engagement. In Journal of applied psychology.

38. Meryer Meyer, J., \& Allen, N. (1991). A three-component conceptualization of organizational commitment. Human Resource Management Review, 1 , 61-89.

39. Mehta, S., Singh, T., Bhakar, S., \& Sinha, B. (2010). Teacher Loyalty towards Organization. 98- 108.

40. Morter, J.R. (2010). Relationship of role overload to job satisfaction and intent to leave among acute care nurses. Unpublished Doctorate Dissertation, University of Phoenix, Department of Educational Leadership, U.S.A.

41. Netemeyer, R.G., Johnston, M.W. \& Burton, S. (1990). Analysis of role conflict and ambiguity in structured equations framework. Journal of Applied Psychology, 75, (April)148-57.

42. Qaiser Danish, R., Ali, N., Fawad Ali, H., Afzal Humayon, A., Bilal Ahmad, M., \& Gohar, A. (2019). Spirit and Innovation at Work in Software Houses of Pakistan: How Does Job Satisfaction Intervene the Relationship?. European Online Journal of Natural and Social Sciences: Proceedings, 8(1 (s)), pp-66.

43. Reglin, G., \& Reitzammer, A. (2008). A Dealing with Stress. Teachers Educational Journal, 118, 590-597.

44. Syed, A., Ahmad, M. B., Ali, H. F., Arif, M. M., \& Gohar, A. (2018). Work-Family Conflict and Turnover Intentions: Moderated Mediation Model. Human Resource Research.

45. Selye, H. A. (1978). Stress without Distress. Philadelphia, PA: Lipincott.

46. Shah, J., Ali, A., \& Khan, I. (2012). A Critical Appraisal of the Social Status of Teachers in Peshawar, Capital of Khyber Pakhtunkhwa, Pakistan. International Journal, 2(1), 176-186.

47. Singh, J., Goolsby, J.R. \& Rhoads, G.K. (1994). Behavioral and psychological consequences of boundary spanning burnout for 
customer service representatives. Journal of Marketing Research,16(558-69.

48. Schulze, S., \& Steyn, T. (2007). Stressors in the professional lives of South African secondary school educators. South African Journal of Education, 27,691-707.

49. Safaria, T., Othman, A., \& Wahab, M.N.A. (2011). Role Ambiguity, Role Conflict, the Role of Job Insecurity as Mediator toward Job Stress among Malay Academic Staff: A SEM Analysis Journal of Social Sciences 3(3): 229-235.

50. Sonentag, S., Volmer, J. \& Sychala, A. (2010). Job Performance.

51. Selamat, N., Samsu, N. Z., \& Kamalu, N. S. M. (2013). The impact of organizational climate on teachers job performance. Educational Research. Vol. 2 No. 1.

52. Silvestro, R., \& Cross, S. (2000). Applying the service-profit chain in a retail environment: challenging the satisfaction mirror. International Journal of Service Industry Management 11 (3), 244-268.

53. Sutherland, W.J., \& Hill, D.A. eds (2004). Managing Habitats for Conservation, Cambridge University Press.

54. Seller, R. M., \& Damas, A. J. (2002). One role or two? The function of psychological separation in role conflict. Journal of Applied Psychology, 87(3), 574-582.

55. Tetrick, L. E., \& Larocco, J. M. (1987). Understanding, Prediciton, and Control as Moderators of the Relationship Between Perceived Stress, Satisfaction, and Psychological Well-being. Journal of Applied Psychology, 72(4), 538-543.

56. Terera, S.R., \& Ngirande, H. (2014). The Impact of Rewards on Job Satisfaction and Employee Retention, Mediterranean Journal of Social Sciences, MCSER Publishing, Rome-Italy, EISSN 2039-2117, Vol. 5, No 1.

57. Taştan, S.B. (2014a). The theoretical implications of job demandsresources model: A research study on the relations of job demands, supervisor support and job autonomy with work engagement. Atatürk University Journal of Economics and Administrative Sciences, 28(4), 149-195.

58. Usman Ahmad, M., Qaiser Danish, R., Fawad Ali, H., Shahid, R., \& Nadeem, K. (2019). Impact of Training and Supervisor Support on Organizational Commitment with mediating role of Job Satisfaction. European Online Journal of Natural and Social Sciences: Proceedings, $8(1(\mathrm{~s})), \mathrm{pp}-25$.

59. Ubom, I. U. \& Joshua, M. T. (2004). "Needs satisfaction variables as predictors of job satisfaction of employees: implication for guidance and counseling", Educational Research Journal, Vol.4.No. 
60. Van der Doef, M., \& Maes, S. (1999). The job demand-control (support) model and psychological well-being: a review of 20 years of empirical research. Work \& Stress, 13(2), 87-114.

61. Vanishree, P. (2014). Impact on role ambiguity, role conflict and role overload on job stress in Small and Medium scale industries. Research Journal of Management Science, 3(1), 10-13.

62. Winefield, G, N., Stough, C., Dua, J., Hapuarachchi, J., \& Boyd, C. (2003). Occupational negative relationship with and job resources like decision Stress in Australian University Staff: Results from National Survey. International Journal of Stress Management, 10(1): 51-63.

63. Westman, M., \& Eden, D. (1996). The inverted-U relationship between stress and performance: A field study. Work and Stress, 10, 165-173.

64. White, E. (2006). Opportunity knocks and it pays a lot better, The Wall Street Journal, November 13.

65. Yousef, D.A. (2000). The interactive effects of role conflict and role ambiguity on job satisfaction and attitudes toward organizational change; A moderated multiple regression approach, International Journal of Stress Management, 7(4), 289-303.

66. Yousef, D. A. (2002). Job satisfaction as a mediator of the relationship between role stressors and organizational commitment: A study from an Arabic cultural perspective. Journal of Managerial Psychology, 17, 250-266. 